\title{
Pengaruh Zakat dan Kesempatan Kerja terhadap Tingkat Kemiskinan di Aceh
}

\section{The Effect of Zakah Revenues and Job Creation on Poverty Rates in Aceh}

\author{
Khairul Amri \\ FEBI UIN Ar-Raniry, Darussalam, Banda Aceh, Indonesia 23111 \\ e-mail: khairul.amri@ar-raniry.ac.id
}

\begin{abstract}
This study aims to analyze the effect of zakah revenues and job creation on poverty rates. Using a panel data set of 23 districts in Aceh for the period of 2011-2017, a fixed-effect method of the panel regression model and the Granger causality test was utilized to analyze the functional relationships between the three variables. The study found out that the zakah revenue and job creation have a negative and significant effect on poverty rates. However, the negative effect of job creation on poverty rates is greater than the negative effect of zakah revenues. The Granger causality test indicates that there is bidirectional causality between poverty rates and zakah revenues and between employment creation and poverty rates. Conversely, there is no causality between zakah revenues and job creations.
\end{abstract}

Key words: Zakah revenue, job creation, poverty rates

\begin{abstract}
Abstrak. Penelitian ini bertujuan untuk menganalisis pengaruh penerimaan zakat dan kesempatan kerja terhadap tingkat kemiskinan. Menggunakan data panel $23 \mathrm{kabupaten/kota} \mathrm{di} \mathrm{Aceh} \mathrm{selama} \mathrm{periode} \mathrm{tahun}$ 2011-2017, model regresi panel metode fixed effect dan Granger causality test digunakan untuk menganalisis hubungan fungsional antara ketiga variabel tersebut. Penelitian menemukan bahwa penerimaan zakat dan kesempatan kerja berpengaruh negatif dan signifikan terhadap tingkat kemiskinan. Namun, pengaruh negatif kesempatan kerja terhadap tingkat kemiskinan lebih besar dibandingkan pengaruh negatif penerimaan zakat. Hasil Granger causality test mengindikasikan bahwa terdapat kausalitas dua arah antara tingkat kemiskinan dan penerimaan zakat, dan antara kesempatan kerja dan tingkat kemiskinan. Sebaliknya, tidak terdapat kausalitas antara penerimaan zakat dan kesempatan kerja.
\end{abstract}

Kata kunci: Penerimaan zakat, kesempatan kerja, tingkat kemiskinan

\section{PENDAHULUAN}

Penurunan tingkat kemiskinan menjadi tujuan utama kebijakan pembangunan ekonomi setiap negara. Kemiskinan merupakan kondisi ketidakberdayaan masyarakat dalam memenuhi kebutuhan hidup mereka secara layak. Dalam konteks daerah, suatu masyarakat dikatakan miskin apabila mereka memiliki pendapatan di bawah nilai nominal tertentu yang ditetapkan sebagai garis kemiskinan. Semakin rendah pendapatan suatu masyarakat, maka semakin besar kemungkinan mereka masuk dalam jurang kemiskinan. Oleh karena itu, upaya yang dilakukan oleh pemerintah dalam mengatasi masalah kemiskinan adalah merealisasikan rencana pembangunan yang beorientasi pada peningkatan pendapatan masyarakat dengan cara membuka lapangan kerja. Sehingga penciptaan lapangan kerja menjadi isu utama pembangunan ekonomi suatu wilayah (Amri \& Nazamuddin, 2018).

Dalam masyarakat Muslim, upaya mengurangi tingkat kemiskinan dapat dilakukan melalui penyaluran dana zakat kepada kelompok miskin. Ajaran Islam dengan tegas menempatkan kelompok tersebut sebagai mustahik zakat (orang yang berhak menerima zakat) di samping fakir, amil zakat, mualaf dan al-gharim (orang yang terlilit utang). Penyaluran zakat berarti terjadinya aliran sebagian pendapatan muzaki (kelompok masyarakat yang wajib membayar zakat) ke mustahik zakat. Oleh karena itu, zakat dapat dijadikan sebagai salah satu instrumen untuk menyelesaikan persoalan kemiskinan dari dimensi pendapatan (Pratama, 2015). Penyaluran dana zakat juga diharapkan dapat mengurangi ketimpangan pendapatan di masyarakat. 
Seiring dengan meningkatnya anggaran dana belanja daerah di Aceh, pemerintah daerah tersebut terus berupaya menurunkan tingkat kemiskinan melalui sejumlah kebijakan pembangunan seperti peningkatan infrastruktur jalan, pembangunan irigasi untuk meningkatkan perkembangan di sektor pertanian, kebijakan investasi baik investasi dalam negeri maupun investasi asing, dan kebijakan lainnya yang bertujuan untuk meningkatkan kesempatan kerja dan pendapatan masyarakat (Amri, 2014). Sebagai daerah yang hampir $97 \%$ penduduknya Muslim, upaya pengentasan kemiskinan juga dilakukan melalui pengelolaan dana zakat. Implementasi syariah Islam di Aceh berimplikasi bahwa pemerintah daerah ini melembagakan pengelolaan zakat dengan dibentuknya Baitul Mal (Amri \& Marwiyati, 2019). Hal ini bertujuan agar penerimaan dan penyaluran zakat dapat dikelola secara lebih baik. Lembaga tersebut tidak hanya bertindak sebagai institusi pengumpul dana, zakat tetapi juga menyalurkan dana tersebut kepada mustahik zakat yang salah satunya adalah kelompok miskin.

Kendatipun pemerintah daerah telah berupaya meningkatkan kesempatan kerja dan melembagakan pengelolaan zakat untuk mengurangi tingkat kemiskinan, namun kenyataannya Aceh masih dihadapkan pada tingkat kemiskinan yang tinggi. Hingga Maret 2019, Aceh merupakan daerah dengan tingkat kemiskinan tertinggi ke -6 di Indonesia setelah Papua, Papua Barat, Nusa Tenggara Timur, Maluku, dan Gorontalo. Dengan jumlah penduduk miskin mencapai 819 ribu jiwa (15.32\%), tingkat kemiskinan Aceh paling tinggi di Sumatera (BPS Aceh, 2019). Bahkan sebelumnya, sejumlah penelitian mencatat bahwa daerah ini tidak hanya dihadapkan persoalan kemiskinan, tetapi juga peningkatan ketimpangan pendapatan di masyarakat (Amri, 2017).

Kajian mengenai keterkaitan antara kemiskinan dengan kesempatan kerja dan penerimaan zakat telah dilakukan oleh sejumlah peneliti. Namun, temuan mereka belum memberikan kesimpulan yang sama. Penelitian yang dilakukan Lanjouw dan Shariff (2002) di India menemukan bahwa kesempatan kerja tidak berkontribusi secara signifikan terhadap penurunan kemiskinan. Kurangnya kepemilikan aset bagi kelompok miskin menyebabkan mereka sulit untuk keluar dari garis kemiskinan. Berbeda dengan temuan tersebut, hasil penelitian Islam (2004) menyimpulkan bahwa peningkatan kesempatan kerja dapat menurunkan tingkat kemiskinan. Konsisten dengan temuan Islam, penelitian empiris yang dilakukan Imai, et al. (2015) untuk kasus perekonomian Vietnam dan India juga menemukan bahwa perluasan kesempatan kerja dapat menurunkan tingkat kemiskinan.

Hasil kajian sejumlah peneliti berkaitan dengan dampak zakat terhadap tingkat kemiskinan juga belum masih memberikan kesimpulan yang paradoks. Murniati dan Beik (2015) dalam penelitian mereka di Bogor menyimpulkan bahwa pemberian zakat kepada mustahik berpengaruh nyata terhadap pendapatan mereka dan menurunkan tingkat kemiskinan di daerah tersebut. Sebelumnya, penelitian Aisyah (2014) juga menyimpulkan bahwa dana zakat memiliki peran yang esensial dalam mengurangi kemiskinan. Sebaliknya, berbeda dengan dua peneliti tersebut, penelitian empiris yang dilakukan Mubarokah, et al. (2017) terhadap 100 orang mustahik penerima dana zakat dari Baznas Jawa Tengah menemukan bahwa indeks kemiskinan islami di masyarakat tanpa dan dengan penyaluran zakat tidak mengalami perubahan yang signifikan. Hal ini mengindikasikan bahwa penyaluran zakat belum memiliki dampak signifikan terhadap perbaikan kondisi ekonomi mustahik.

Selain menghasilkan temuan yang tidak konsisten, penelitian yang dilakukan oleh sejumlah peneliti di atas hanya menempatkan kemiskinan sebagai variabel endogen dengan menggunakan zakat dan kesempatan kerja sebagai predictor variable. Padahal kemampuan seseorang dalam membayar zakat juga terkait dengan sejauh mana mereka dapat bekerja dan meningkatkan pendapatan mereka. Hal ini secara implisit menginformasikan bahwa penerimaan zakat di suatu daerah juga terkait dengan kesempatan kerja dan kemiskinan itu sendiri. Sehingga ketiga variabel tersebut dapat berperan sebagai eksogen sekaligus endogen. Berbeda dengan sejumlah peneliti sebelumnya, penelitian ini didasarkan pada data sekunder dalam bentuk data panel kabupaten/kota di Aceh.

Guna mempertajam analisis mengenai keterkaitan antara ketiga variabel tersebut, tidak hanya digunakan peralatan ekonometrika regresi panel, tetapi juga panel Granger causality test untuk menganalisis arah hubungan kausalitas antar variabel. Sehingga kajian ini tidak hanya berfokus pada 
pengaruh penerimaan zakat dan kesempatan kerja terhadap tingkat kemiskinan, tetapi juga signifikansi kemiskinan dalam menjelaskan penerimaan zakat dan kesempatan kerja di Aceh.

\section{TINJAUAN PUSTAKA}

\section{Keterkaitan antara Penerimaan Zakat dengan Kemiskinan}

Membayar zakat telah menjadi kewajiban bagi setiap Muslim yang telah memenuhi syarat wajib zakat (muzaki). Menurut ajaran Islam, dana zakat diberikan kepada kelompok masyarakat penerima zakat (mustahik) yang salah satunya adalah kelompok miskin. Hal tersebut dilakukan dengan tujuan untuk membantu mereka dalam memenuhi kebutuhan hidup layak. Dalam konteks sosial masyarakat Muslim, zakat dapat memberikan dampak yang lebih luas (multiplier effect) dan menyentuh semua aspek kehidupan mereka. Dana zakat dapat mendukung skema keamanan sosial secara kolektif dan juga bermanfaat untuk pembangunan sosial (Abdullah \& Suhaib, 2011). Bahkan, zakat dapat dijadikan alat untuk memperbaiki distribusi pendapatan di masyarakat (Hayati \& Caniago, 2011).

Peran dan efektivitas dana zakat dalam mengatasi persoalan kemiskinan telah menjadi sorotan para peneliti ekonomi syariah. Namun, signifikansi dampak dana tersebut dalam mengurangi tingkat kemiskinan masih menjadi perdebatan di antara peneliti. Sejumlah peneliti menemukan bukti kuat bahwa dana zakat secara signifikan mampu menurunkan tingkat kemiskinan di masyarakat. Contohnya adalah hasil kajian Mohamed, et al. (2019) di Selangor Malaysia yang menyimpulkan bahwa zakat dapat digunakan sebagai alat untuk mengurangi tingkat kemiskinan.

Agak berbeda dengan temuan peneliti di atas, penelitian lain mengungkapkan bahwa kontribusi zakat terhadap penurunan kemiskinan relatif kecil (Redha, et al., 2016). Sebelumnya, kajian Ali, et al. (2015) di Kelantan Malaysia juga mengindikasikan bahwa sekalipun zakat dapat meningkatkan pendapatan kelompok miskin, namun efek zakat terhadap pendapatan mereka relatif kecil. Temuan tersebut sejalan dengan hasil kajian Hoque, et al. (2015) yang mengungkapkan bahwa zakat dapat memperbaiki kondisi ekonomi mustahik, namun tidak berdampak signifikan pada penurunan jumlah penduduk miskin.

Bertolak belakang dengan penelitian di atas, sejumlah peneliti membuktikan tidak adanya hubungan yang signifikan antara tingkat kemiskinan dengan penerimaan dan penyaluran zakat. Seperti halnya Nurjanah, et al. (2019) dalam kajian mereka di Jawa Barat menemukan bukti empiris bahwa secara parsial penyaluran zakat tidak berpengaruh terhadap jumlah penduduk miskin. Sebelumnya, hasil kajian Johari, et al. (2014) tentang peran zakat dalam mengurangi kemiskinan dan ketimpangan pendapatan mualaf di Selangor Malaysia, mengungkapkan temuan yang hampir sama. Temuan tersebut berupa dampak zakat terhadap penurunan kemiskinan relatif kecil. Artinya penyaluran zakat tidak secara signifikan menurunkan kemiskinan. Hasil penelitian Khasandy dan Badrudin (2019) yang menggunakan data agregat untuk kasus Indonesia juga mengungkapkan bahwa zakat belum secara nyata berdampak pada peningkatan dan kesejahteraan masyarakat.

\section{Keterkaitan antara Kesempatan Kerja dengan Kemiskinan}

Kesempatan kerja merupakan salah satu variabel ekonomi makro yang telah lama menjadi fokus kajian para peneliti ekonomi (Muliadi \& Amri, 2019). Hal ini disebabkan kesempatan kerja menjadi salah satu indikator ekonomi yang mencerminkan kinerja perekonomian suatu wilayah. Peningkatan kesempatan kerja dapat meningkatkan output perekonomian dan pada gilirannya berdampak pada penurunan tingkat kemiskinan (Zivanomoyo \& Mukoka, 2015). Peran penting kesempatan kerja dalam meningkatkan pertumbuhan ekonomi dan mengurangi tingkat kemiskinan berimplikasi bahwa kebijakan pembangunan ekonomi berorientasi pada penciptaan lapangan kerja (Amri \& Nazamuddin, 2018). 
Secara konseptual, hubungan antara kesempatan kerja dan kemiskinan dapat dianalisis dalam tingkatan makro dan mikro. Dalam tingkatan makro, hubungan antara kemiskinan dalam dimensi pendapatan dan kesempatan kerja dapat dikonseptualisasikan dalam bentuk kurangnya ketersediaan lapangan kerja sehingga sebagian angkatan kerja tidak mampu memperoleh pekerjaan. Mereka tidak hanya berpendapatan rendah, bahkan tidak memiliki pendapatan sama sekali (Islam, 2004). Dalam tingkatan mikro, kesempatan kerja dikaitkan dengan kurangnya kemampuan dan keterampilan kerja sehingga seorang angkatan kerja terpaksa menganggur (Amri, 2018).

Keterkaitan antara kesempatan kerja dan kemiskinan telah menjadi perhatian sejumlah peneliti. Namun hasil kajian mereka mengenai arah dan signifikansi hubungan antara kedua variabel tersebut belum memberikan kesimpulan yang seragam. Hubungan antara kemiskinan dan kesempatan kerja berbentuk non linier dan digambarkan dalam model garis kuadratik (quadratic line model) dengan dua simpul optimal (two optimal knots), kemiskinan meningkat ketika pengangguran lebih kecil dari $3.87 \%$ dan sebaliknya akan menurun ketika pengangguran berkisar antara 3.87\% - 4.24\% (Budiantara, et al., 2011).

Adetunji, et al. (2012) menyatakan bahwa terdapat hubungan antara kesempatan kerja dengan tingkat kemiskinan. Namun demikian, tidak semua kesempatan kerja mampu memberikan dampak negatif bagi kemiskinan. Perkembangan kesempatan kerja di sektor petanian secara signifikan mampu mengurangi tingkat kemiskinan. Sebaliknya, penyerapan tenaga kerja di sektor perdagangan tidak secara nyata dapat menurunkan tingkat kemiskinan, terutama di negara yang mayoritas penduduknya bekerja di sektor pertanian. Berbeda dengan kedua peneliti tersebut, penelitian Nassar dan Biltagy (2017) memberikan kesimpulan bahwa secara umum kemiskinan terkait dengan kurangnya kesempatan kerja dan rendahnya tingkat upah. Hal ini secara implisit dapat dimaknai bahwa kesempatan kerja dan nominal upah yang diterima oleh pekerja merupakan determinan tingkat kemiskinan.

\section{METODE}

Data yang digunakan dalam penelitian ini adalah data sekunder. Data tersebut berbentuk data panel yang terdiri dari data time series (runut waktu) selama periode tahun 2011-2017 ( $\mathrm{n}=7$ ) dan data kerat silang (cross section data) yang diambil dari 23 kabupaten/kota di Aceh. Data kemiskinan dan kesempatan kerja bersumber dari Badan Pusat Statistik (BPS) Aceh. Selanjutnya data penerimaan zakat bersumber dari Baitul Mal Aceh. Data dari Baitul Mal Aceh merupakan data riil penerimaan zakat yang kemudian juga dipublikasikan oleh BPS Aceh.

Guna memenuhi kepentingan analisis kuantitatif mengenai keterkaitan antara ketiga variabel, perlu dijelaskan pengukuran masing-masing variabel. Penerimaan zakat diproksi dari penerimaan zakat per kapita yang dihitung dengan satuan rupiah per kapita. Kesempatan kerja adalah jumlah angkatan kerja yang mampu memperoleh pekerjaan dinyatakan dengan satuan jiwa. Selanjutnya tingkat kemiskinan dihitung berdasarkan rasio jumlah penduduk yang hidup di bawah garis kemiskinan dengan total penduduk diukur dengan satuan persen.

Model ekonometrika yang digunakan dalam menganalisis pengaruh penerimaan zakat dan kesempatan kerja terhadap tingkat kemiskinan adalah regresi panel.Penggunaan model ekonometrika tersebut didasarkan pada alasan bahwa estimasi mengenai hubungan fungsional antar variabel pada dasarnya menggunakan data panel seperti dijelaskan di atas.Secara ekonometrik model regresi panel tersebut diformulasikan sebagai berikut.

$$
\mathrm{MSK}_{\mathrm{it}}=\beta_{0}+\beta_{1} \mathrm{ZKT}_{\mathrm{it}}+\beta_{2} \mathrm{KK}_{\mathrm{it}}+e_{\mathrm{it}}
$$




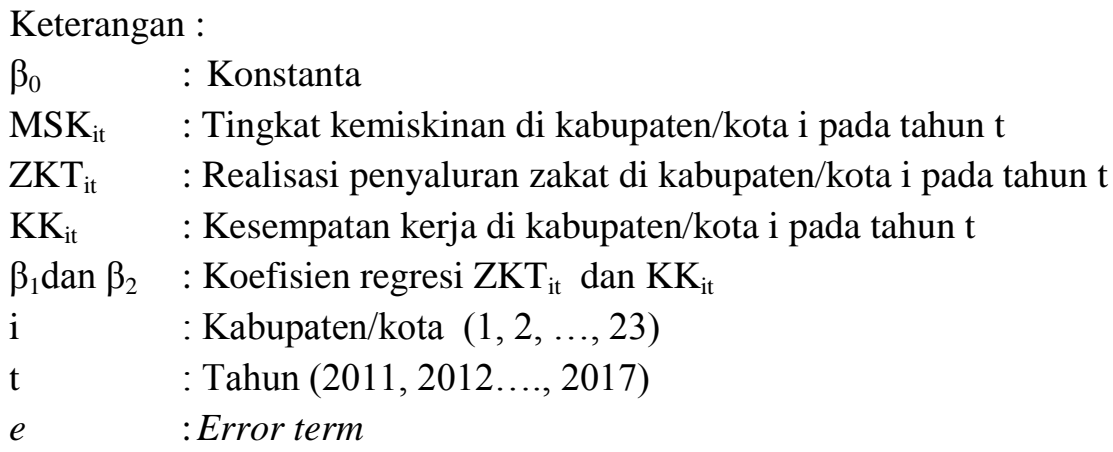

Mengingat masing-masing variabel memiliki ukuran berbeda, diperlukan adanya proses transformasi data dalam bentuk logaritma, sehingga persamaan 1 tersebut modifikasi menjadi persamaan 2 .

$$
\mathrm{LMSK}_{\mathrm{it}}=\beta_{0}+\beta_{1} \mathrm{LZKT}_{\mathrm{it}}+\beta_{2} \mathrm{~L} \mathrm{KK}_{\mathrm{it}}+e_{\mathrm{it}}
$$

Keterangan :

$\beta_{0} \quad$ : Konstanta

LMSK $_{\text {it }} \quad$ : Logaritma tingkat kemiskinan di kabupaten/kota i pada periode $\mathrm{t}$

$\mathrm{LZKT}_{\text {it }} \quad$ : Logaritma realisasi belanja modal di kabupaten/kota i pada periode $\mathrm{t}$

$\mathrm{LKK}_{\text {it }} \quad$ : Logaritma kesempatan kerjadi kabupaten/kota i pada periode $\mathrm{t}$

$\beta_{1} \quad:$ Koefisien regresi LZKT $_{\text {it }}$

$\beta_{2} \quad$ : Koefisien regresi $\mathrm{LKK}_{\mathrm{it}}$

i : Kabupaten/kota $(1,2, \ldots, 23)$

t $\quad:$ Tahun $(2011,2012 \ldots ., 2017)$

e : Error term

Regresi panel memiliki tiga pendekatan yaitu common effect model, fixed effect model dan random effect model. Untuk menentukan mana di antara tiga pendekatan tersebut yang paling akurat untuk memprediksi pengaruh zakat dan kesempatan kerja terhadap tingkat kemiskinan, digunakan Chow test dan Hausman test. Chow test dimaksudkan untuk menentukan model terbaik antara common effect model atau fixed effect model yang dinilai lebih baik. Sedangkan Hausman test menentukan pilihan terbaik antara fixed effect model atau random effect model (Muliadi \& Amri, 2019).

Penentuan signifikansi pengaruh salah satu predictor variable (penerimaan zakat atau kesempatan kerja) secara parsial terhadap tingkat kemiskinan didasarkan pada nilai $p$-value yang dihasilkan oleh proses pengolahan data dengan menggunakan software E-Views, dengan ketentuan jika suatu variabel memiliki nilai $p$-value $<0.05$ berarti variabel tersebut berpengaruh signifikan. Sebaliknya, jika memiliki nilai $p$-value $>0.05$ berarti tidak berpengaruh signifikan. Selanjutnya pengujian signifikansi pengaruh kedua predictor variable tersebut (secara simultan) digunakan statistik uji $\mathrm{F}$, dengan ketentuan jika $p$-value $<0.05$ berarti kedua variabel secara simultan berpengaruh signifikan terhadap tingkat kemiskinan. Sebaliknya $p$-value $>0.05$ secara statistik menginformasikan bahwa kedua variabel tidak berpengaruh signifikan.

Selanjutnya untuk menganalisis arah kausalitas antar variabel digunakan panel Granger causality test. Model ekonometrik ini pada dasarnya merupakan pengembangan dari uji hubungan kausalitas pada data time series yang sebelumnya dikembangkan Granger (Lopez \& Weber, 2017). Melalui panel causality test dapat diketahui apakah kausalitas antar variabel berbentuk kausalitas satu (unidirectional) atau kausalitas dua arah (bidirectional causality). Hubungan antara tingkat kemiskinan dan penerimaan zakat misalnya, mengacu pada pendapat Dumitrescu \& Hurlin (2012) untuk mendeteksi kausalitas antara kedua variabel tersebut dapat dilakukan proses regresi seperti dalam persamaan 3 . 


$$
L M S K_{i, t}=\propto_{i}+\sum_{k=1}^{K} \gamma_{i k} L M S K_{i, t-k}+\sum_{k=1}^{K} \beta_{i k} L Z K T_{i, t-k}+\varepsilon_{i, t}
$$

Keterangan :

i $\quad: 1, \ldots 0$

$\mathrm{t} \quad: 1, \ldots \mathrm{t}$

LMSK $_{i, t}$ : Logaritma tingkat kemiskinan pada kabupaten/kota i dalam periode $\mathrm{t}$

$L Z K T_{i, t} \quad$ : Penerimaan zakat per kapita pada kabupaten/kota i pada periode

$\mathrm{K} \quad$ : Lag order (durasi waktu) antara salah satu atau kedua variabel berdampak pada variabel lainnya. Diasumsikan identik untuk setiap data.

Penentuan adanya indikasi kausalitas antar variabel didasarkan pada nilai $p$-value yang dihasilkan melalui proses perhitungan statistik. Jika $p$-value $<0.05$ berarti terdapat kausalitas antar variabel. Sebaliknya jika $p$-value $>0.05$ mengindikasikan tidak adanya kausalitas.

\section{HASIL DAN PEMBAHASAN}

Tingkat kemiskinan, penerimaan zakat, dan kesempatan kerja masing-masing daerah di Aceh relatif berbeda satu sama lainnya. Perbedaan tersebut tidak hanya terjadi antar kabupaten/kota, tetapi juga pada daerah yang sama dalam periode waktu yang berbeda. Pada tahun 2017 daerah dengan tingkat kemiskinan tertinggi adalah Gayo Lues (21.77\%), kemudian menyusul Aceh Singkil (21.50\%) dan Bener Meriah (21.32\%). Sebaliknya daerah dengan kemiskinan terendah adalah Banda Aceh (7.38\%), kemudian menyusul Langsa (11.04\%) dan Lhokseumawe (11.93\%). Dalam periode tahun yang sama, daerah dengan penerimaan zakat per kapita paling tinggi adalah Sabang (Rp 96,516.20), kemudian menyusul Aceh Tengah (Rp 83,457.90) dan Bener Meriah (Rp 58,753.20). Sebaliknya daerah dengan penerimaan zakat paling rendah adalah Pidie ( $\mathrm{Rp} 758.80$ ), kemudian menyusul Aceh Timur (Rp 8,983.60) dan Bireuen (Rp 9,165.30).

Berkaitan dengan kesempatan kerja, pada tahun 2017, daerah dengan kesempatan kerja paling tinggi adalah Aceh Utara (201,554 jiwa), kemudian menyusul Bireuen sebesar 178,251 jiwa dan Pidie di urutan ketiga dengan kesempatan kerja sebesar 171,233 jiwa. Untuk lebih jelasnya mengenai hasil statistik dekriptif dan korelasi antar variabel dapat dilihat Tabel 1.

Tabel 1 Hasil statistik deskriptif dan korelasi antar variabel

\begin{tabular}{lccc}
\hline \multicolumn{4}{c}{ Statistik Deskriptif } \\
\hline & $\begin{array}{c}\text { Tingkat Kemiskinan } \\
\text { (Persen) }\end{array}$ & $\begin{array}{c}\text { Penerimaan } \\
\text { Zakat (Rp/Kapita) }\end{array}$ & $\begin{array}{c}\text { Kesempatan } \\
\text { Kerja (Jiwa) }\end{array}$ \\
\hline Mean & 18.41 & $23,221.55$ & 83,741 \\
Maximum & 26.10 & $96,516.20$ & 211,686 \\
Minimum & 7.38 & 758.80 & 11,227 \\
\hline \multicolumn{4}{c}{ Korelasi Antar Variabel } \\
\hline Tingkat Kemiskinan & 1 & 1 & 1 \\
Penerimaan Zakat & -0.181 & -0.251 & 1 \\
Kesempatan Kerja & -0.152 & &
\end{tabular}

Sumber: Data Sekunder, 2019(diolah)

Tabel 1 memperlihatkan arah hubungan antara ketiga variabel. Tingkat kemiskinan berhubungan negatif dengan penerimaan zakat dan kesempatan kerja. Hal itu ditunjukkan oleh nilai koefisien korelasi masing-masing sebesar -0.181 dan -0.152 . Hal tersebut mengindikasikan adanya hubungan tidak searah antara kemiskinan di satu sisi dengan penerimaan zakat dan kesempatan kerja di sisi lain. Semakin tinggi penerimaan zakat, maka semakin rendah tingkat kemiskinan. Peningkatan penerimaan zakat oleh Baitul Mal sejalan dengan peningkatan penyaluran zakat kepada mustahik yang pada gilirannya dapat mengurangi kemiskinan secara umum. Demikian pula halnya dengan kesempatan kerja. Peningkatan jumlah angkatan kerja yang mampu memperoleh pekerjaan berdampak pada 
pendapatan agregat dalam konteks kabupaten/kota di Aceh secara umum yang pada akhirnya juga mengurangi tingkat kemiskinan di daerah tersebut.

Hubungan antara penerimaan zakat dan kesempatan kerja juga negatif dengan koefisien korelasi sebesar -0.251 . Hal ini mengindikasikan bahwa peningkatan jumlah angkatan kerja yang mampu memperoleh pekerjaan belum secara langsung dapat meningkatkan penerimaan zakat. Kendatipun hubungan negatif antara kedua variabel tersebut sangat lemah, namun secara implisit menginformasikan bahwa peningkatan lapangan kerja belum secara signifikan berdampak pada peningkatan jumlah muzaki dan besaran dana zakat yang masuk melalui Baitul Mal sebagai lembaga pengelola zakat di Aceh.

Tingkat kemiskinan yang relatif tinggi di sebagian daerah kabupaten/kota di Aceh belum serta merta dapat meningkatkan jumlah pembayar zakat ketika pemerintah berhasil meningkatkan lapangan kerja di daerah tersebut. Terjadinya peningkatan pendapatan masyarakat sebagai respons terhadap perbaikan kesempatan kerja belum mampu meningkatkan kemampuan mereka dalam membayar zakat, melainkan hanya pada perbaikan kualitas konsumsi guna memenuhi kebutuhan hidup seharihari. Hal inilah yang menyebabkan tidak adanya hubungan searah antara kesempatan kerja dan penerimaan zakat.

Sebagaimana dijelaskan sebelumnya, model analisis yang digunakan untuk menganalisis pengaruh penerimaan zakat dan kesempatan kerja terhadap tingkat kemiskinan adalah regresi panel. Model ekonometrika tersebut terdiri dari tiga pendekatan yakni common effect model, fixed effect model dan random effect model. Untuk menentukan mana di antara tiga pendekatan tersebut yang paling tepat digunakan sebagai alat estimasi, digunakan Chow test dan Hausman test. Chow test digunakan untuk menentukan apakah menggunakan model common effect atau fixed effect, sedangkan Hausman test digunakan untuk menentukan apakah menggunakan model fixed effect atau random effect. Uji Chow test untuk menentukan apakah model yang dipilih common effect atau fixed effect didasarkan pada nilai $p$-value untuk cross-section $F$ dengan ketentuan jika $p$-value $>0.05$, maka model adalah common effect. Sebaliknya jika $p$-value $<0.05$ maka model yang dipilih adalah fixed effect. Hasil uji Chow test ditunjukkan dalam Tabel 2.

Tabel 2 Hasil Chow test

\begin{tabular}{ccccc}
\hline Uji Efek & & Statistic & df & p-value \\
\hline Cross-Section & Cross-section F & 123.470 & $(22.136)$ & 0.000 \\
Fixed Effects & Cross-section Chi-square & 489.962 & 22 & 0.000 \\
\hline
\end{tabular}

Sumber: Data Sekunder, 2019 (diolah)

Berdasarkan Tabel 2 dapat dilihat bahwa nilai p-value cross section $\mathrm{F}$ sebesar $0.000<0.05$. Dengan demikian dapat disimpulkan bahwa berdasarkan Chow test, model yang dipilih adalah fixed effect model.

Selanjutnya uji Hausman test digunakan untuk menentukan apakah model yang dipilih fixed effect atau random effect. Pemilihan salah satu di antara kedua model tersebut didasarkan pada nilai $p$ value cross-section random dengan ketentuan jika nilai $p$-value $>0.05$ maka model yang dipilih adalah random effect. Sebaliknya jika nilai $p$-value $<0.05$ maka model yang dipilih adalah fixed effect. Hasil uji Hausman test seperti ditunjukkan dalam Tabel 3.

Tabel 3 Hasil Hausman test

\begin{tabular}{cccc}
\hline Uji Efek & $\mathbf{X}^{2}$-Statistic & df & p-value \\
\hline Cross-Section Random Effects & 6.825 & 2 & 0.033 \\
\hline
\end{tabular}

Sumber: Data Sekunder, 2019 (diolah)

Tabel 3 memperlihatkan nilai $\mathrm{X}^{2}$-Statistik sebesar 6.825 dan nilai $p$-value sebesar 0.033. Nilai $\mathrm{X}^{2}$-tabel pada tingkat keyakinan $95 \%$ pada $\mathrm{df}=2$ sebesar 5.991. Karena nilai $\mathrm{X}^{2}$-Statistik $>\mathrm{X}^{2}$-tabel $(6.825>5.991)$, dan nilai $p$-value $<0.05$ maka dapat disimpulkan bahwa fixed effect model lebih baik bila dibandingkan dengan random effect model. Sebelumnya hasil Chow test (Tabel 2) juga mengindikasikan bahwa model terbaik juga fixed effect model. Justifikasi statistik yang 
menyimpulkan bahwa fixed effect model dinilai lebih baik dibandingkan random effect model juga dapat didasarkan pada perbandingan gambar residual yang dihasilkan oleh kedua metode tersebut seperti ditunjukkan dalam Gambar 1 dan 2.

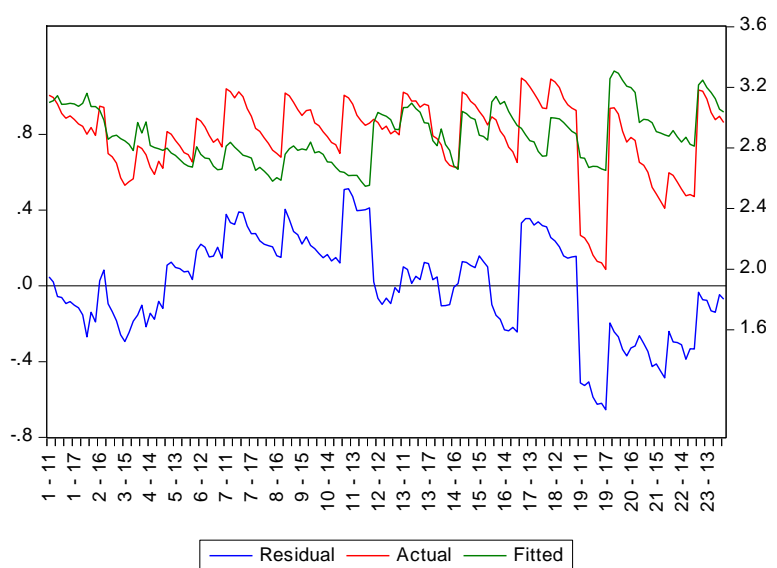

Sumber: Output Eviews, 2019

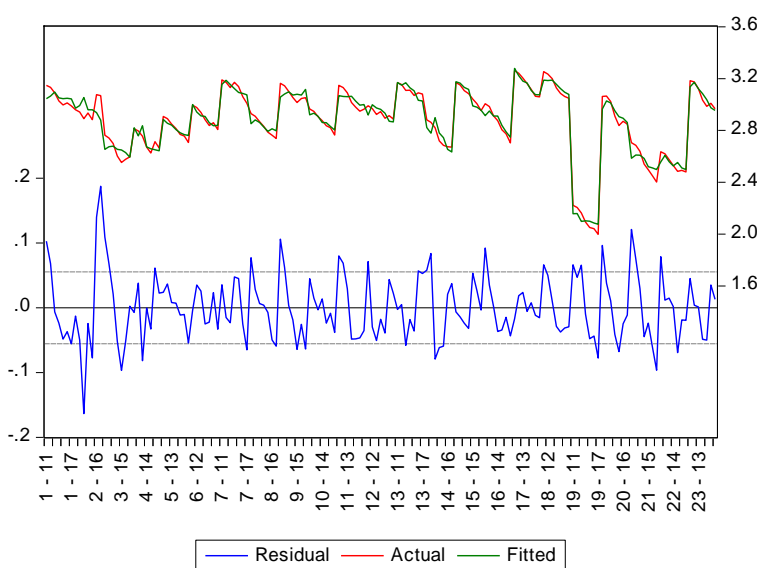

Sumber: Output Eviews, 2019

Gambar 1 Residual metode random effect model

Gambar 1 memperlihatkan residual yang dihasilkan dari pendekatan random effect model. Pada gambar tersebut terlihat bahwa variasi/fluktuasi garis actual cenderung berbeda dengan fluktuasi garis fitted. Selanjutnya, Gambar 2 memperlihatkan residual regresi panel yang dihasilkan oleh pendekatan fixed effect model. Pada gambar tersebut terlihat bahwa variasi/fluktuasi garis actual hampir sama dengan fluktuasi garis fitted. Berdasarkan perbandingkan garis actual dan garis fitted pada kedua gambar tersebut dapat disimpulkan bahwa pendekatan fixed effect model menghasilkan estimasi yang lebih akurat bila dibandingkan dengan pendekatan random effect model. Karena itu, regresi panel yang dipilih dan kemudian digunakan untuk kepentingan analisis dalam penelitian ini adalah fixed effect model.

Ketepatan estimasi dengan menggunakan regresi panel sebagai alat analisis data tidak terlepas dari adanya asumsi klasik terutama asumsi normalitas residual dan asumsi multikoliniearitas. Berdasarkan output Eviews, estimasi pengaruh penerimaan zakat dan kesempatan kerja terhadap kemiskinan seperti dijelaskan sebelumnya sudah memenuhi asumsi normalitas residual. Hal ini ditunjukkan oleh Gambar 3.

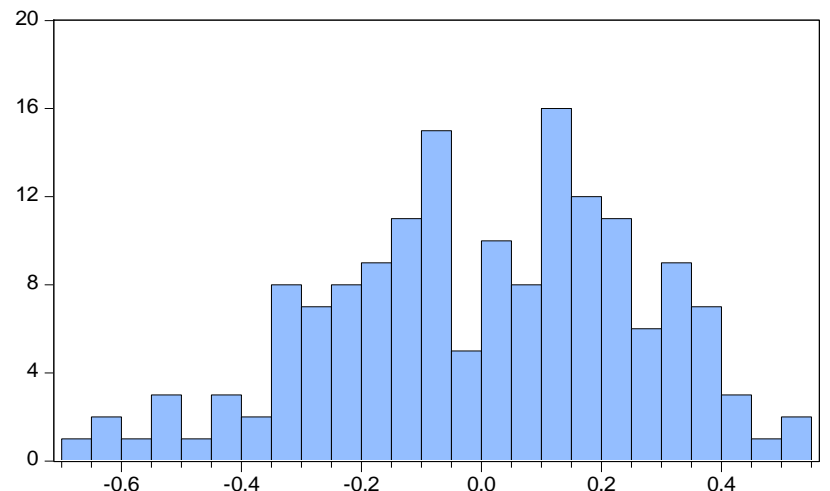

Sumber: Output Eviews, 2019

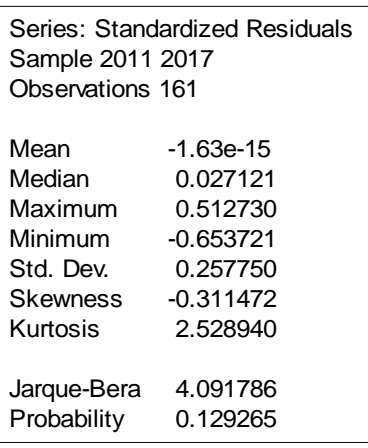

Probability 0.129265

Gambar 3 Normalitas residual 
Gambar 3 memperlihatkan nilai $J-B$ test sebesar 4.092 dengan prob sebesar 0.129 (> 0.05). Dengan demikian dapat diartikan bahwa residual estimasi terdistribusi secara normal.

Pengujian gejala multikoliniearitas dalam model regresi panel dilakukan dengan membandingkan nilai adjusted- $R^{2}$ yang dihasilkan dari proses regresi dengan nilai koefisien korelasi (r) antara sesama predictor variable. Predictor variable dalam kajian ini adalah penerimaan zakat dan kesempatan kerja. Koefisien korelasi antar variabel seperti ditunjukkan dalam Tabel 4.

Tabel 4 Koefisien korelasi antar variabel

\begin{tabular}{cccc}
\hline & LMSK & LZKT & LKK \\
\hline LMSK & 1.000 & & \\
LZKT & -0.203 & 1.000 & \\
LKK & -0.229 & -0.383 & 1.000 \\
\hline
\end{tabular}

Sumber: Data Sekunder , 2019 (diolah)

Tabel 4 menunjukkan nilai koefisien korelasi (r) antara penerimaan zakat (LZKT) dan kesempatan kerja (LKK) menunjukkan angka negatif sebesar 0.383. Angka ini lebih kecil dari nilai adjusted- $R^{2}$ pada regresi panel sebesar 0.952 . Hal ini berarti model regresi panel yang digunakan untuk memprediksi pengaruh penerimaan zakat dan kesempatan kerja terhadap tingkat kemiskinan tidak memiliki gejala multikoliniearitas.

\section{Analisis Pengaruh Zakat dan Kesempatan Kerja terhadap Tingkat Kemiskinan}

Penerimaan zakat dan kesempatan kerja berpengaruh negatif terhadap tingkat kemiskinan di Aceh. Hal ini dapat dilihat dari koefisien estimasi kedua variabel independen tersebut bernilai negatif seperti ditunjukkan dalam rangkuman hasil regresi panel dalam Tabel 5.

Tabel 5 Ringkasan hasil regresi panel

Dependent Variable: LMSK

Method: Panel Least Squares

\begin{tabular}{ccccc}
\hline Variable & Coefficient & Std. Error & t-Statistic & P-Value \\
\hline C & 7.580 & 0.519 & 14.592 & 0.000 \\
LZKT & -0.063 & 0.012 & -5.324 & 0.000 \\
LKK & -0.367 & 0.050 & -7.276 & 0.000 \\
\hline
\end{tabular}

$\mathrm{R}^{2}=0.959 ;$ adjusted- $R^{2}=0.952 ;$ F-statistic $=134.333 ; \operatorname{Prob}(F$-test $)=0.000 ;$

Durbin-Watson test $=0.953 ;$ p-value $<0.05$ signifikan pada keyakinan $95 \%$.

Sumber: Data Sekunder, 2019 (diolah)

Berdasarkan Tabel 5 maka hubungan fungsional antara tingkat kemiskinan dengan penerimaan zakat dan kesempatan kerja dapat dinyatakan dalam persamaan 4 .

$\mathrm{LMSK}_{\mathrm{it}}=7.580-0.063 \mathrm{LZKT}_{\mathrm{it}}-0.367 \mathrm{LKK}_{\mathrm{it}}$

Penerimaan zakat berpengaruh negatif dan signifikan terhadap tingkat kemiskinan di Aceh. Hal ini ditunjukkan oleh koefisien estimasi sebesar -0.063 ( $p$-value $=0.000<0.05)$. Secara statistik, angka tersebut dapat diinterpretasikan bahwa setiap peningkatan penerimaan zakat per kapita sebesar $1 \%$ dapat menurunkan tingkat kemiskinan sebesar $0.063 \%$. Adanya dampak signifikan penerimaan zakat terhadap penurunan tingkat kemiskinan disebabkan zakat yang dikumpulkan oleh Baitul Mal masingmasing kabupaten/kota di Aceh secara langsung disalurkan kepada mustahik zakat yang umumnya adalah kelompok fakir dan miskin. Semakin besar penerimaan zakat oleh lembaga tersebut, maka semakin besar pula ketersediaan dana zakat yang disalurkan kepada kelompok miskin. Zakat tersebut tidak hanya zakat konsumtif yang digunakan mustahik untuk memenuhi kebutuhan konsumsi mereka, tetapi juga zakat produktif dalam bentuk bantuan modal usaha, barang modal dan alat-alat produksi yang dapat mendukung pengembangan usaha produktif yang mereka lakukan. 
Adanya pengaruh negatif dan signifikan zakat terhadap tingkat kemiskinan sejalan dengan hasil penelitian Abdelbaki (2013) yang menyimpulkan bahwa dana zakat dapat menurunkan tingkat kemiskinan di negara-negara Muslim. Apalagi bila dana tersebut dimanfaatkan mustahik untuk kegiatan ekonomi produktif maka dapat mengurangi tingkat pengangguran dan memperbaiki distribusi pendapatan di masyarakat. Temuan ini juga mengkonfirmasi hasil penelitian Redha, et al. (2016) di Algeria yang menemukan bahwa dana zakat berdampak pada penurunan tingkat kemiskinan.

Namun, bertolak belakang dengan hasil kajian Isiaka, et al. (2015) di Nigeria yang menemukan bahwa zakat tidak secara signifikan berhubungan dan tidak efektif dalam mengurangi kemiskinan masyarakat Muslim di negara tersebut. Temuan tersebut sejalan dengan temuan Khasandy \& Badrudin (2019) di Indonesia yang menyimpulkan zakat tidak memiliki pengaruh terhadap kesejahteraan masyarakat. Bahkan kesejahteraan masyarakat di negara tersebut mengalami penurunan diindikasikan oleh turunnya Indeks Pembangunan Manusia dan meningkatnya ketimpangan pendapatan.

Kesempatan kerja juga berpengaruh negatif dan signifikan terhadap tingkat kemiskinan ditunjukkan oleh kofisien estimasi sebesar -0.367 ( $p$-value $=0.000<0.05$ ). Peningkatan kesempatan kerja sebesar $1 \%$ mendorong penurunan tingkat kemiskinan sebesar $0.367 \%$ dengan asumsi penerimaan zakat tidak berubah. Hal tersebut mengindikasikan bahwa penciptaan lapangan kerja di Aceh telah mampu meningkatkan pendapatan masyarakat sehingga jumlah masyarakat yang hidup di bawah garis kemiskinan menurun. Daerah dengan kesempatan kerja relatif lebih besar menyebabkan penduduk yang berada di bawah garis kemiskinan di daerah tersebut semakin kecil, sehingga terdapat hubungan terbalik antara kemiskinan dan kesempatan kerja.

Temuan tersebut memperkuat hasil penelitian Seran (2017) yang menyimpulkan bahwa peningkatan kesempatan kerja tidak hanya berpengaruh positif terhadap pendapatan masyarakat, tetapi juga berdampak pada penurunan tingkat kemiskinan. Hasil tersebut juga sejalan dengan kesimpulan penelitian Niranjan \& Shivakumar (2017) di India yang juga membuktikan bahwa penurunan kemiskinan di negara tersebut secara signifikan dipengaruhi oleh peningkatan kesempatan kerja.

Guna menganalisis arah hubungan kausalitas antara ketiga variabel digunakan panel Granger causality test. Hasil pengujian menunjukkan bahwa terdapat kausalitas dua arah antara kemiskinan dan penerimaan zakat. Artinya, antara kedua variabel tersebut saling mempengaruhi satu sama lainnya. Penerimaan zakat mempengaruhi tingkat kemiskinan dan tingkat kemiskinan juga mempengaruhi penerimaan zakat. Dengan kata lain, terjadinya perubahan penerimaan zakat di suatu daerah merupakan respons terhadap perubahan tingkat kemiskinan di daerah tersebut. Demikian pula halnya perubahan tingkat kemiskinan merupakan respons terhadap perubahan penerimaan zakat.

Hanya saja, pengaruh kemiskinan terhadap penerimaan zakat terjadi pada lag 1. Ini mengindikasikan bahwa kemiskinan pada periode $t$, berpengaruh terhadap penerimaan zakat periode berikutnya $(t+1)$. Tingkat kemiskinan secara langsung berdampak pada penurunan kemampuan masyarakat dalam membayar zakat. Hal inilah yang secara statistik dijelaskan oleh time lag 1 tersebut. Peningkatan kemiskinan di daerah tertentu berarti semakin banyaknya jumlah masyarakat yang masuk dalam golongan mustahik. Dalam periode waktu yang sama, jumlah muzaki mengalami penurunan. Sehingga terdapat trade-off antara tingkat kemiskinan di satu sisi dengan jumlah pembayar zakat di sisi lain.

Selanjutnya pengaruh penerimaan zakat terhadap tingkat kemiskinan terjadi pada lag 4. Ini berarti peningkatan penerimaan zakat pada periode t secara signifikan menyebabkan penurunan kemiskinan empat tahun kemudian $(\mathrm{t}+4)$. Adanya durasi waktu (time lag) pengaruh penerimaan zakat terhadap kemiskinan disebabkan zakat yang disalurkan baitul mal kepada mustahik tidak semuanya dalam bentuk zakat produktif. Ada juga yang disalurkan dalam bentuk zakat konsumtif untuk memenuhi kebutuhan dasar mustahik. Sehingga dalam jangka pendek penyaluran zakat hanya membantu 
pemenuhan kebutuhan konsumsi mereka. Lain halnya ketika dana zakat disalurkan dalam bentuk zakat produktif. Zakat produktif dapat meningkatkan kemampuan produksi dan memberikan dampak pendapatan dalam jangka panjang dan berkelanjutan, sehingga mereka dapat keluar dari jurang kemiskinan. Hal inilah yang menyebabkan adanya durasi waktu yang relatif panjang dalam hubungan kausalitas antara penerimaan zakat terhadap penurunan tingkat kemiskinan.

Adanya kausalitas dari zakat ke kemiskinan secara statistik mengindikasikan bahwa penurunan tingkat kemiskinan merupakan respons terhadap penyaluran zakat produktif. Hal ini disebabkan zakat produktif biasanya disalurkan dalam bentuk modal kerja bagi mustahik yang sudah memiliki usaha. Bahkan dalam banyak kasus, penyaluran zakat produktif oleh baitul mal di Aceh kepada mustahik diwujudkan dalam bentuk penyediaan barang modal yang disesuaikan dengan kebutuhan usaha penerima zakat tersebut, sehingga secara langsung dapat berdampak pada peningkatan produksi dan perkembangan usaha mereka.

Temuan tersebut mengkonfirmasi hasil penelitian Redha, et al. (2016) yang menemukan bahwa penyaluran zakat produktif dapat meningkatkan perkembangan usaha penerima zakat dan menurunkan tingkat kemiskinan. Sebelumnya, temuan penelitian Abdelbaki (2013) juga menyimpulkan bahwa zakat dapat mengurangi tingkat kemiskinan dan memperbaiki distribusi pendapatan di masyarakat. Sebaliknya, temuan tersebut bertolak belakang dengan hasil kajian Khasandy \& Badrudin (2019) yang menyimpulkan bahwa zakat tidak mempengaruhi kesejahteraan masyarakat.

Tabel 6 Hasil Granger causality test

\begin{tabular}{ccccccc}
\hline \multirow{2}{*}{$\begin{array}{c}\text { Variabel } \\
\text { Endogen }\end{array}$} & \multicolumn{7}{c}{ Variabel Eksogen } \\
\cline { 2 - 7 } & LMSK & LKK & LZKT & LMSK & LKK & LZKT \\
\cline { 2 - 7 } LMSK & - & {$[0.008]$} & {$[0.138]$} & - & {$[0.302]$} & {$[0.143]$} \\
& & $(0.930)$ & $(0.711)$ & - & $(0.739)$ & $(0.867)$ \\
LKK & {$[0.174]$} & - & {$[0.088]$} & {$[\mathbf{3 . 1 6 2}]$} & - & {$[1.182]$} \\
& $(0.678)$ & - & $(0.767)$ & $(\mathbf{0 . 0 4 6})^{* *}$ & - & $(0.311)$ \\
LZKT & {$[\mathbf{2 . 8 3 9}]$} & {$[0.202]$} & - & {$[0.669]$} & {$[0.069]$} & - \\
& $(\mathbf{0 . 0 9 4})^{*}$ & $(0.654)$ & - & $(0.514)$ & $(0.933)$ & - \\
\hline \multirow{7}{*}{ Lag 3 } & LKK & LZKT & LMSK & LKK & LZKT \\
\hline \multirow{3}{*}{ LMSK } & LMSK & {$[1.352]$} & {$[1.165]$} & - & {$[1.232]$} & {$[\mathbf{2 . 2 8 0}]$} \\
& - & $(0.263)$ & $(0.328)$ & & $(0.307)$ & $(\mathbf{0 . 0 7 1})^{*}$ \\
LZKT & {$[\mathbf{2 . 8 2 1}]$} & - & {$[1.830]$} & {$[1.215]$} & - & {$[0.470]$} \\
& $(\mathbf{0 . 0 4 4})^{* *}$ & - & $(0.148)$ & $(0.314)$ & - & $(0.757)$ \\
& {$[0.976]$} & {$[0.412]$} & - & {$[0.344]$} & {$[1.047]$} & - \\
\hline
\end{tabular}

Sumber: Data Sekunder, 2019 (diolah)

Angka dalam [ ] adalah nilai $F$-statistic, dan ( ) adalah nilai $p$-value

*) signifikan pada keyakinan $90 \%$

**) signifikan pada keyakinan $95 \%$

Tabel 6 menginformasikan bahwa kausalitas dua arah juga terjadi antara kemiskinan dan kesempatan kerja pada lag 2 dan lag 3. Hal ini mengindikasikan bahwa perubahan kesempatan kerja merupakan respons terhadap tingkat kemiskinan. Ketika tingkat kemiskinan tinggi, daya beli masyarakat menurun. Hal tersebut berdampak pada penurunan permintaan barang dan jasa di masyarakat, sehingga kegiatan produksi menurun dan pada akhirnya mempengaruhi kesempatan kerja.

Perubahan tingkat kemiskinan juga merupakan respons terhadap kesempatan kerja. Ketika kesempatan kerja meningkat, pendapatan masyarakat juga meningkat dan pada gilirannya berdampak 
pada penurunan tingkat kemiskinan. Hal ini konsisten dengan hasil regresi sebelumnya yang menunjukkan bahwa kesempatan kerja berpengaruh negatif terhadap tingkat kemiskinan.

Hasil Granger causality test tidak memperlihatkan adanya kausalitas dari penerimaan zakat ke kesempatan kerja. Hal ini mengindikasikan bahwa dana zakat di Aceh belum secara nyata mampu mendorong perluasan kesempatan kerja di masyarakat. Kendatipun dana zakat disalurkan dalam bentuk zakat produktif, hanya berdampak positif terhadap peningkatan usaha dan perbaikan kualitas hidup penerima zakat tersebut, tetapi belum mampu mendorong penciptaan lapangan kerja secara signifikan. Inilah yang menyebabkan tidak adanya kausalitas dari penerimaan zakat ke kesempatan kerja. Temuan ini mendukung hasil penelitian Mohamed, et al. (2019) di Selangor Malaysia yang menyimpulkan bahwa kendatipun zakat dapat mengurangi tingkat kemiskinan, namun tidak memberikan dampak pada penurunan tingkat pengangguran.

\section{SIMPULAN}

Upaya pemerintah daerah dalam mengentaskan kemiskinan di Aceh tidak hanya dilakukan melalui kebijakan yang berorientasi pada perluasan kesempatan kerja, tetapi juga melalui penyaluran zakat oleh Baitul Mal sebagai lembaga pengelola zakat. Penelitian ini menganalisis pengaruh kesempatan kerja dan penyaluran zakat terhadap penurunan kemiskinan di Aceh. Menggunakan data dari 23 kabupaten/kota selama periode 2011-2017, panel regresi metode fixed effect dan Granger causality test dioperasionalkan untuk menguji hubungan fungsional antar variabel tersebut. Penelitian menemukan bahwa peningkatan kesempatan kerja dan zakat berpengaruh negatif dan signifikan terhadap kemiskinan di Aceh. Namun demikian, dampak negatif penyaluran zakat terhadap kemiskinan lebih kecil dibandingkan dengan dampak negatif kesempatan kerja.

Hasil Granger causality test mengindikasikan adanya kausalitas dua arah antara penerimaan zakat dan kemiskinan, dan antara kemiskinan dan kesempatan kerja. Sebaliknya tidak terdapat kausalitas antara penerimaan zakat dan kesempatan kerja. Hal ini mengindikasikan bahwa penerimaan zakat mempengaruhi tingkat kemiskinan, demikian pula halnya tingkat kemiskinan juga mempengaruhi penerimaan zakat. Peningkatan tingkat kemiskinan berdampak pada penurunan penerimaan zakat menyebabkan dana zakat yang dapat disalurkan Baitul Mal kepada mustahik juga menurun. Sehingga perubahan penerimaan zakat merupakan respons terhadap perubahan tingkat kemiskinan, dan perubahan tingkat kemiskinan juga merupakan respons terhadap terjadinya perubahan dalam penerimaan zakat.

Adanya kausalitas dua arah antara tingkat kemiskinan dan kesempatan kerja di Aceh secara eksplisit mengindikasikan bahwa kesempatan kerja di daerah tersebut terkait dengan pendapatan dan daya beli masyarakat. Dalam kondisi kemiskinan tinggi, daya beli masyarakat menurun. Akibatnya permintaan terhadap barang dan jasa dalam perekonomian juga menurun. Kondisi ini pada gilirannya mendorong dunia usaha untuk mengurangi kegiatan produksi sehingga berdampak pada penurunan penggunaan tenaga kerja. Di sisi lain, perubahan dalam penyerapan tenaga kerja juga berdampak pada pendapatan masyarakat yang pada akhirnya juga mempengaruhi tingkat kemiskinan itu sendiri.

Mengacu pada kesimpulan di atas, maka intervensi kebijakan yang perlu dilakukan oleh pemerintah daerah dalam upaya pengentasan kemiskinan di Aceh adalah sebagai berikut :

1. Mengoptimalkan penerimaan dana zakat oleh Baitul Mal kabupaten/kota. Secara operasional upaya tersebut dapat dilakukan dengan cara meningkatkan instensitas sosialisasi mengenai fungsi dan peran lembaga tersebut dalam mengelola dana zakat. Hal ini bertujuan untuk meningkatkan kesadaran muzaki agar menjadikan Baitul Mal sebagai alternatif pilihan utama ketika ingin membayar zakat.

2. Pendistribusian dana zakat oleh Baitul Mal kepada mustahik sebaiknya menempatkan zakat produktif dalam porsi yang lebih besar dibandingkan zakat konsumtif. Jika memungkinkan, 
penyaluran zakat produktif kepada seorang calon penerima zakat didasarkan pada skala prioritas yakni kelompok miskin yang benar-benar memiliki usaha produktif. Sehingga penggunaan dana tersebut memberikan multiplier effect yang lebih besar bagi perekonomian daerah secara umum.

3. Dalam upaya penurunan tingkat kemiskinan di Aceh, pemerintah daerah perlu meningkatkan kesempatan kerja di seluruh kabupaten/kota. Alokasi belanja pembangunan dalam meningkatkan perekonomian di daerah harus berorientasi pada sektor-sektor yang dapat menyerap tenaga kerja lebih besar, seperti sektor pertanian dan perkebunan. Apalagi sebagian besar masyarakat di Aceh bekerja di dua sektor ini.

\section{DAFTAR PUSTAKA}

Abdelbaki, H. H. (2013). The impact of zakat on poverty and income inequality in Bahrain. Review Integrative Business \& Economy, 2(1),133-154.

Abdullah, M., \& Suhaib, A. Q. (2011). The Impact of zakat on social life of muslim society. Pakistan Journal of Islamic Research, 8, 85-91.

Adetunji Babatunde, M., Oyeranti, O. A., Bankole, A. S., \& Olawale Ogunkola, E. (2012). Exports trade, employment and poverty reduction in Nigeria. International Journal of Social Economics, 39(11), 875-899.

Aisyah, M. (2014).The role of zakah and binary economics in poverty reduction, ESENSI:Jurnal Bisnis dan Manajemen, 4(2), 178-197.

Ali, A. F. M., Rashid, Z. A., Johari, F., \& Aziz, M. R. A. (2015). The effectiveness of zakat in reducing poverty incident: An analysis in Kelantan, Malaysia. Asian Social Science, 11(21), 355-367.

Amri, K. (2014). Infrastruktur transportasi dan kepadatan penduduk dampaknya terhadap pendapatan per kapita: Panel Data Evidence dari sembilan provinsi di Sumatera. Jurnal Ekonomi Manajemen dan Bisnis, 2(2), 438-450.

Amri, K. (2017). Analisis pertumbuhan ekonomi dan ketimpangan pendapatan: Panel data 8 provinsi di Sumatera. Jurnal Ekonomi dan Manajemen Teknologi, 1(1), 1-11.

Amri, K. (2018). The macroeconomic impact of regional minimum wages: A cross-provinces data evidence from Indonesia. Regional Science Inquiry, 10(3), 163-176.

Amri, K., \& Nazamuddin. (2018). Is there causality relationship between export and employment: A time series data evidence from Indonesia. International Journal of Academic Research in Economics and Management Sciences, 7(2), 86-99.

Amri, K., \& Marwiyati. (2019). Preferensi muzakki membayar zakat melalui baitul mal: Studi empiris di Kota Banda Aceh. Jurnal Manajemen dan Sains, 4(2), 386-391.

Budiantara, I. N., Diana, R., Purhadi.,\& Darmesto, S. (2011). Relationship pattern of poverty and unemployement in Indonesia with bayesian spline approach. International Journal of Basic \& Applied Sciences, 11(6), 119-127.

Dumitrescu, E.-I, \& Hurlin, C. (2012). Testing for Granger non causality in heterogeneous panels. Economic Modelling, 29,1450-1460.

Hayati, K., \& Caniago, I. (2011). Zakat potential as a means to overcome poverty (A Study in Lampung). Journal of Indonesian Economy and Business, 26(2), 187-200.

Hoque, N., Khan, M. A., \& Mohammad, K. D. (2015). Poverty alleviation by zakah in a transitional economy: A small business entrepreneurial framework. Journal of Global Entrepreneurship Research, 5(1).

Islam, R. (2004) The Nexus of Economic Growth, Employment and Poverty Reduction: An Empirical Analysis. Discussion Paper 14, International Labour Office, Geneva 
Imai, K., Gaiha, R. \& Thapa, G. (2015). Does non-farm sector employment reduce rural poverty and vulnerability? Evidence from Vietnam and India. Journal of Asian Economics, 36, 47-61.

Isiaka, A. O., Johari, F., \& Alias, M. (2015). Is zakah effective to alleviate poverty in a muslim society?: A case of Kwara State, Nigeria. Global Journal Al Thaqafah, 5(1), 33-41.

Johari, F., Aziz, M. R. A., \& Ali, A. F. M. (2014). The role of zakat in reducing poverty and income inequality among new convert (muallaf) in Selangor, Malaysia. Online Journal Research in Islamic Studies, 1(3), 43-56.

Khasandy, E. A., \& Badrudin, R. (2019). The influence of zakat on economic growth and welfare society in Indonesia. Integrated Journal of Business and Economics, 65-79.

Lanjouw, P., \& Shariff, A. (2002). Rural non-farm employment in India: Access, income and poverty impact. Economic and Political Weekly, 4429-4446.

Lopez, L., \& Weber, S. (2017). Testing for Granger causality in panel data. The Stata Journal, 17(4), 927-984.

Mohamed, A. S. Bin, Ibrahim, A. A. Bin, Zaidi, N. S. B., \& Kamaruzaman, M. N. Bin. (2019). Does zakah significantly impact on economic growth in Selangor, Malaysia?. International Journal of Academic Research in Business and Social Sciences, 9(6), 786-807.

Mubarokah, I., Beik, I. S., \& Irawan, T. (2017). Dampak zakat terhadap kemiskinan dan kesejahteraan mustahik (Kasus: BAZNAS provinsi Jawa Tengah). Al-Muzara'ah, 5(1), 37-50.

Muliadi, \& Amri, K. (2019). Infrastruktur jalan, belanja modal dan kesempatan kerja: Bukti data panel kabupaten kota di Aceh. Jurnal Manajemen dan Sains, 4(2), 334-341.

Murniati, R., \& Beik, I. S. (2015). Pengaruh zakat terhadap indeks pembangunan manusia dan tingkat kemiskinan mustahik: Studi kasus pendayagunaan BAZNAS kota Bogor. Al-Muzara'ah, 2(2), 135-149.

Nassar, H., \& Biltagy, M. (2017). Poverty, employment, investment, and education relationships: The case of Egypt. SAGE Open, 7(2), 2158244017697156.

Niranjan, R., \& Shivakumar. (2017). Poverty and employment generation in India. International Journal of Scientific Research in Multidisciplinary Studies, 3(8), 14-20.

Nurjanah, F., Kusnendi, \& Juliana. (2019). The impact of economic growth and distribution of zakat funds on poverty (Survey in the third district of West Java province period 2011-2016). KnE Social Sciences, 55-70.

Pratama, Y. C. (2015). Peran zakat dalam penanggulangan kemiskinan (Studi kasus : Program zakat produktif pada Badan Amil Zakat Nasional). Tauhidinomics, 1(1), 93-104.

Redha, B. M., Larbi, G., \& Karima, R. M. (2016). The impact of zakat fund in reducing poverty, case of Algeria. Mediterranean Journal of Social Sciences, 7(3), 256-264.

Seran, S. (2017). Relationship of education, unemployment, and economic growth with the poverty of population. International Journal of Current Research, 9(7), 55186-55193.

Zivanomoyo, J.,\& Mukoka, S. (2015). An empirical analysis of the impact of unemployment on economic growth in Zimbabwe. Archieves of Business Research, 3(6), 38-46. 